\title{
OUTDOOR TOURISM, KAYAKING, TOURISM POTENTIAL AND TOURISM OPERATIONS IN CENTRAL- EASTERN EUROPE: THE CASE OF POLAND
}

\author{
Elżbieta LEWANDOWICZ* \\ University Warmia and Mazury in Olsztyn, Faculty of Geoengineering, Institute of Geodesy and Civil \\ Engineering, Department of Geoinformation and Cartography, Olsztyn, Poland e-mail: leela@uwm.edu.pl
}

Joanna BAC-BRONOWICZ

University of Science and Technology, Faculty of Civil Engineering, Wrocław, Department of Geotechnology, Hydro Technology, and Underground and Hydro Engineering, Wrocław, Poland, e-mail: joanna.bac-bronowicz@pwr.edu.pl

\begin{abstract}
Citation: Lewandowicz, E., \& Bac-Bronowicz, J. (2022). OUTDOOR TOURISM, KAYAKING, TOURISM POTENTIAL AND TOURISM OPERATIONS IN CENTRAL- EASTERN EUROPE: THE CASE OF POLAND. GeoJournal of Tourism and Geosites, 40(1), 232-241. https://doi.org/10.30892/gtg.40128-824
\end{abstract}

\begin{abstract}
This article aimed to describe the potential of outdoor tourism in Poland, with emphasis on kayaking tours. Reports and strategy documents generated by the Polish Tourism Organization (PTO), spatial data, and information about tourism operators in Poland were processed and analyzed. An analysis of geographic data and business registers revealed considerable differences across Polish regions and the absence of a sustainable tourism development strategy in Poland. The results do not justify PTO's recommendations for promoting the development of outdoor tourism operators in selected Polish regions. The study demonstrated that in some Polish regions, the development of the tourist industry is contingent on the efforts made by local entrepreneurs, whereas other regions do not tap into their tourism potential despite ample natural resources for the development of water tourism. Entrepreneurship indicators in the outdoor tourism sector have generally increased in the last 46 years, but considerable differences are noted across Polish voivodeships. The study revealed that the development of outdoor tourism is highly fragmented and that strong local hubs of tourist activity exist at the local level. The interest in water tourism has increas ed markedly in the last two years because this form of active recreation promotes social distancing and can be safety practiced during the COVID-19 pandemic. The aim of this article was to describe the potential of outdoor tourism in Poland, with emphasis on kayaking tours. Reports and strategy documents generated by the Polish Tourism Organization (PTO), spatial data, and data about tourism operators in Poland were processed and analyzed. The study revealed that the development of outdoor tourism is highly fragmented and that strong local hubs of tourist activity exist at the local level. Tourists preferences for participating in kayaking tours in different voivodeships do not match the recommendations of the PTO.
\end{abstract}

Key words: outdoor tourism, adventure tourism, ecotourism, kayaking, outdoor tourism potential, tourism operators

$* * * * * *$

\section{INTRODUCTION}

The tourism potential of Central-Eastern Europe was recognized only in 1999 after the political and economic transformations in the region (Ivy and Copp, 1999). Considerable research on the development of tourism in this part of Europe was done in the following decades (Mazurski, 2000; Copp and Ivy, 2001; Marciszewska, 2006; Paesler, 2007; Hughes and Allen, 2009; Saarinen and Jarkko, 2017; Niewiadomski, 2018; Hall, 2020; Klitsounova, 2020). Central-Eastern Europe is open to changes in the tourist market and has vast potential for developing various types of tourism (Grzelak and Roszko-Wójtowicz, 2020). However, the growth of tourism in the region was initially hampered by the scarcity of the accompanying infrastructure, and it was limited to urban or city tourism. This negative trend was reversed as CentralEuropean countries became more affluent. The region's rapid economic growth has led to new recreational development in attractive natural sites and in the vicinity of water bodies. Tourism is a major source of income. It contributes to regional development (Butler et al., 1997; Balaguer and Cantavella-Jorda, 2002), which is why tourism operators should receive support. According to the literature, poorly developed regions in Eastern Europe find it difficult to harness their vast natural and geographic potential for sustainable tourism development (Hegarty and Przezborska, 2005).

The popularity of tourism and water sports is on the rise around the world (Gössling et al., 2012, 2015; Folgado-Fernández et al., 2018). Water bodies are used for a wide variety of outdoor recreational activities, including kayaking, water biking, water motorsports, sailing, windsurfing, scuba diving and iceboating. Water tourism is less popular in Central-Eastern Europe (Folgado-Fernández et al., 2018). However, according to Gössling et al. (2012), domestic and international tourism share in domestic water use is relatively low in Central-Eastern Europe (Figure 1). River and sea kayaking is an increasingly popular category of outdoor tourism. The development of water tourism is strongly linked with the existing natural resources. Fossgard and Fredman (2019) have argued that river regulation projects and water sports involving scooters and motorboats impede the development of kayaking. The COVID-19 pandemic has significantly limited tourist activities (Gössling et al., 2021). However, outdoor tourism was the first sector where restrictions were gradually lifted because outdoor activities

* Corresponding author 
require little social contact and minimize the risk of virus transmission. As a result, the pandemic has transformed the tourist industry. Moreover, the popularity of global tourism has declined in favour of local tourism (Giddy and Webb, 2016; Godtman et al., 2018; Gössling et al., 2021). This trend was initially reported in 2019. Nevertheless, most consumers are still inclined to choose local activities over international travel. Given the growing popularity of outdoor tourism, this study aimed to determine the potential of outdoor tourism (kayaking) in Poland. This goal was achieved by analyzing various sources of data. Finally, the results were presented graphically on maps using Geographic Information System (GIS) tools.

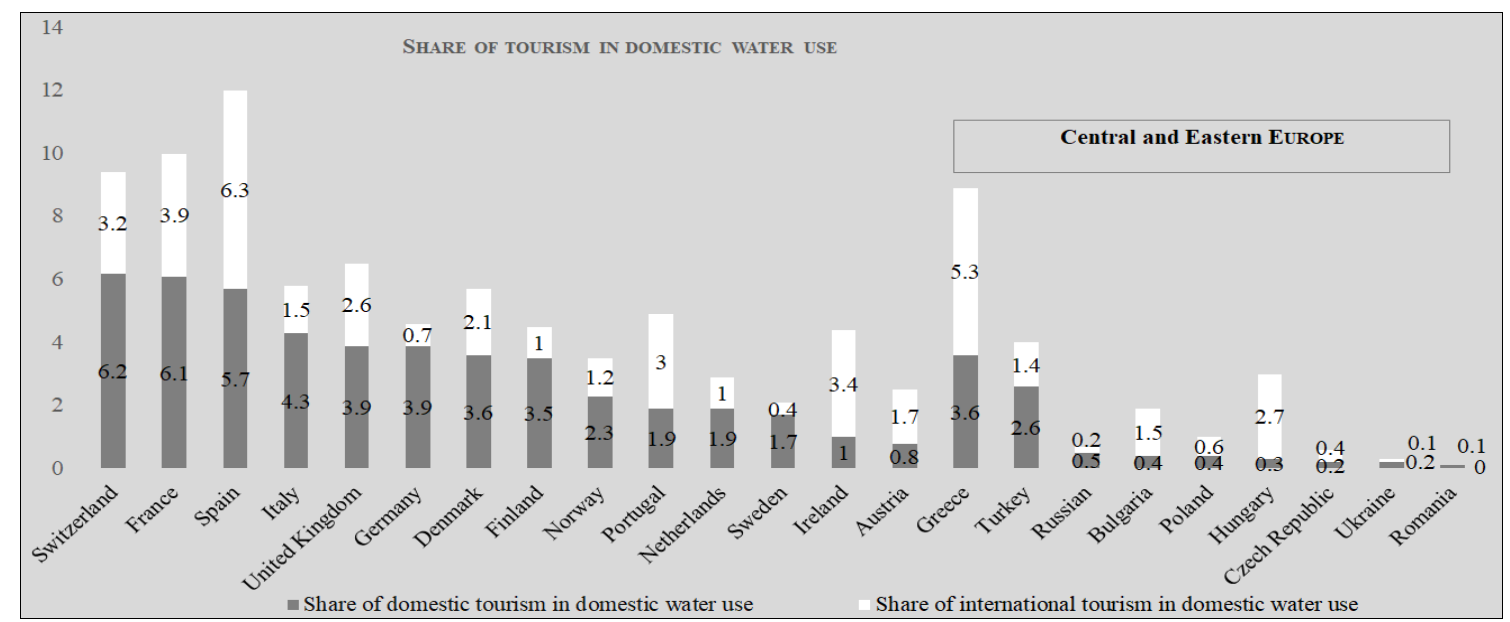

Figure 1. Share of domestic and international tourism in domestic water use (Source: Gössling et al., 2012)
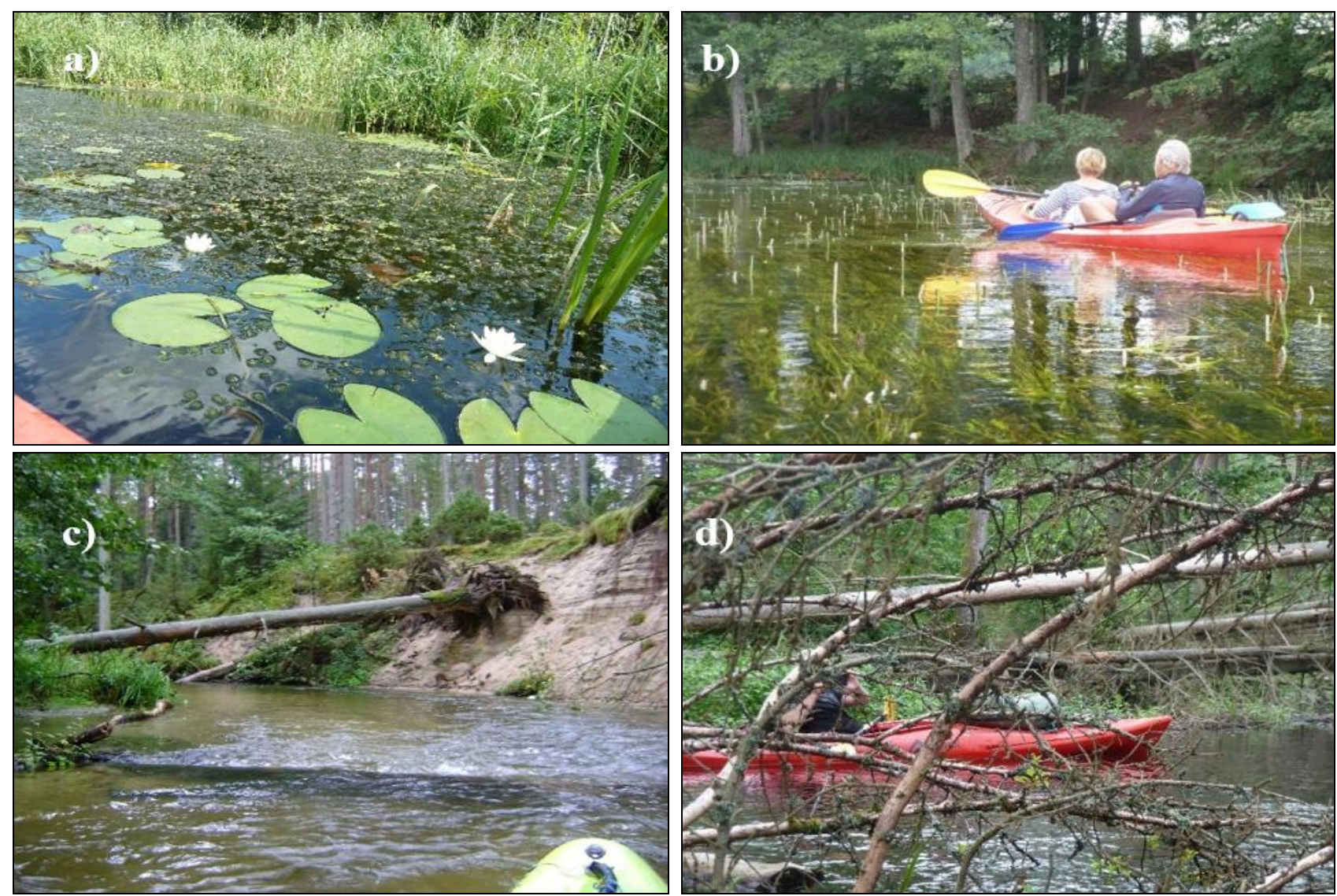

Figure 2. River kayaking in Poland: a) Pisa Warmińska River - nature tourism; b) Czarna Hańcza

River - senior tourism; c) Marózka River - adventure tourism; d) Brda River - hard tourism. Source: own study.

\section{MATERIALS AND METHODS}

Data for the study were acquired from the following sources:

- Polish Tourism Organization (PTO) (strategic documents, reports and market analyses) made available by website (www.pot.gov.pl/pl);

- Spatial databases in the public domain containing topographic data (BDOO_250 and BDOT_10) made available by the Head Office of Geodesy and Cartography on the national geoportal (geoportal.gov.pl);

- Business registers, including the National Court Register (KRS) from Ministry of Justice and the Central Register and Information on Economic Activity (CEIDG) from Ministry of Development and Technology, made available by website of 
the Republic of Poland (gov.pl). In the first stage of the study, the reports and analyses developed by the PTO were used to assess the potential of the Polish tourist market in view of outdoor tourism, including water tourism (kayaking).

In the second stage of the study, an attempt was made to evaluate the potential of water bodies for the development of water tourism in Polish voivodeships. The analysis relied on topographic databases containing bodies of standing water, rivers and water bodies in forests. These databases were analyzed using GIS tools, and the results were visualized on maps.

In the third stage of the study, the data acquired from Ministry of Justice from base KRS and Ministry of Development and Technology from base CEIDG were analyzed to identify tourist associations and tourism operators, in particular operators specializing in outdoor tourism. In addition, the databases developed by CEIDG were used to determine the number of registered businesses that rent tourist equipment, including water sports equipment. Data generated by KRS and CEIDG are available in the form of text and Excel (Xls) files which contain the tourism operator's registered name, address, date of business establishment/closure, and periods when business operations were temporarily suspended. GIS tools were used to localize and visualize these datasets on maps and present changes in the number of registered tourism operators over time.

In the fourth stage of the study, the potential of natural resources, including water bodies, for tourism development was assessed in Polish regions. Various tourist function indicators have been proposed in the literature, including Baretje-Defert's tourist function index, Charvat's index and Schneider's index (Szromek, 2012, 2013; Korzeniewski and Kozłowski, 2020). These indices are expressed relative to reference unit area or population. In the present study, they were also related to Polish regions' geographic (natural) potential. The results of the analyses were presented in tables and maps. Three types of maps were generated for this purpose: vector maps, raster maps covering all of Poland, and cartograms and thematic maps covering Polish voivodeships. Vector maps were developed based on geospatial information acquired from public databases (geoportal.gov.pl): the Database of Geographic Objects in 1:25000 scale (BDOO), the Database of Topographic Objects in 1:10000 scale (BDOT), and the National Register of Geographic Names (PRNG).
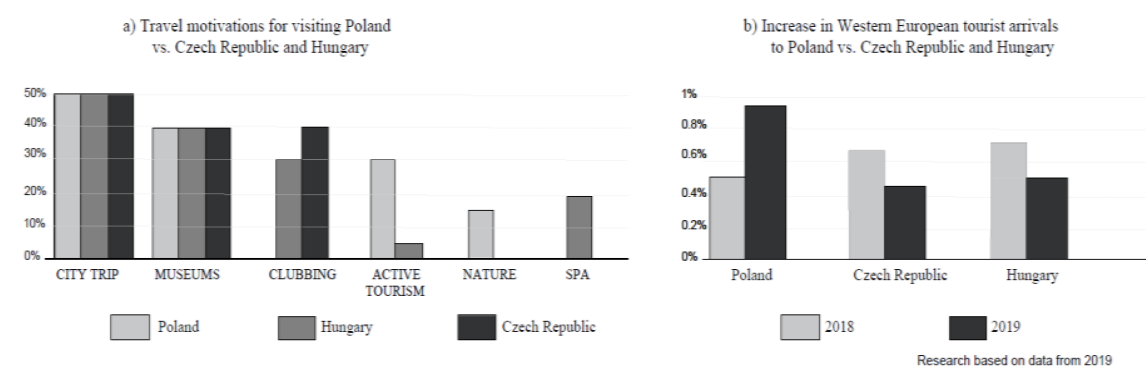

Table 1. Kayaking tours in Polish regions recommended to domestic and German tourists, on a scale of $1(\mathrm{X})$ to $3(\mathrm{XXX})$ points. (XXX (3) - priority, XX (2) - standard, X (1) - secondary, - no marketing activity - (0); (Source: Marketing strategy for the Polish tourist industry for 2012-2020, adopted by the Management Board of the Polish Tourism Organization on 5 December 2011 (PTO, 2011)

Figure 3. Analysis of the Polish tourism market: a) Travel motivations for visiting Poland vs. Czech Republic and Hungary; b) Increase in Western European tourist arrivals to Poland vs. the Czech Republic and Hungary Source: own study on Polish Tourism Organization (2019)

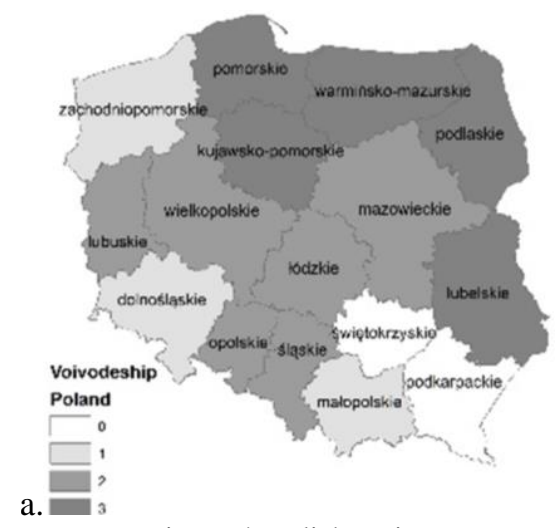

Figure 4. Polish regions recommended for kayaking tours addressed to:

a) domestic tourists; b) German tourists (Source: own study from Table 1)

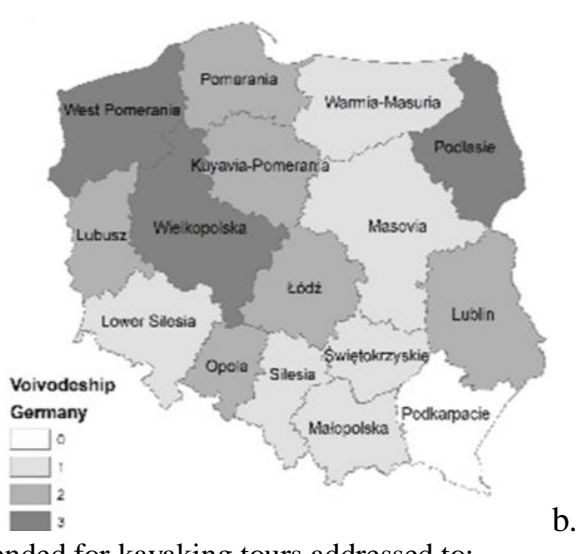

b.

\begin{tabular}{|l|l|l|l|}
\hline \multirow{2}{*}{} & \multirow{2}{*}{ Voivodeship } & \multicolumn{2}{|c|}{$\begin{array}{c}\text { Kayaking tours } \\
\text { targeting domestic } \\
\text { and German tourists }\end{array}$} \\
\cline { 3 - 5 } & & Domestic & German \\
\hline 1 & Lower Silesia & $\mathrm{X}$ & $\mathrm{X}$ \\
\hline 2 & Kuyavia-Pomerania & $\mathrm{XXX}$ & $\mathrm{XX}$ \\
\hline 3 & Lublin & $\mathrm{XXX}$ & $\mathrm{XX}$ \\
\hline 4 & Lubusz & $\mathrm{XX}$ & $\mathrm{XX}$ \\
\hline 5 & Lódź & $\mathrm{XX}$ & $\mathrm{XX}$ \\
\hline 6 & Małopolska & $\mathrm{X}$ & $\mathrm{X}$ \\
\hline 7 & Masovia & $\mathrm{XX}$ & $\mathrm{X}$ \\
\hline 8 & Opole & $\mathrm{XX}$ & $\mathrm{XX}$ \\
\hline 9 & Podkarpacie & - & - \\
\hline 10 & Podlasie & $\mathrm{XXX}$ & $\mathrm{XXX}$ \\
\hline 11 & Pomerania & $\mathrm{XXX}$ & $\mathrm{XX}$ \\
\hline 12 & Silesia & $\mathrm{XX}$ & $\mathrm{X}$ \\
\hline 13 & Swiętokrzyskie & - & $\mathrm{X}$ \\
\hline 14 & Warmia-Masuria & $\mathrm{XXX}$ & $\mathrm{X}$ \\
\hline 15 & Wielkopolska & $\mathrm{XX}$ & $\mathrm{XXX}$ \\
\hline 16 & West Pomerania & $\mathrm{X}$ & $\mathrm{XXX}$ \\
\hline
\end{tabular}

Using geocoding, the text and table data generated by KRS and CEIDG were converted to vector format. A point represented a company's geographic location on the map based on its registered address. Vector data were converted to raster data using density tools based on geographic coordinates and an object's attributes, such as the surface area of a water body or the length of a river segment. Raster maps facilitate a more generalized and vivid presentation of geographic phenomena. Density tools calculate the density of point and line features only; therefore, bodies of standing water were converted to point objects. To generate raster maps, datasets were divided into subsets by calculating quantiles with five class breaks. In the quantile classification method, an equal number of values is assigned to each class, supporting the analysed phenomena' accurate presentation. The results of spatial analyses are generally presented on maps and in tables, and data corresponding to different administrative division units are visualised using cartograms and thematic maps. This form of data presentation was also used in the study. The analyzed data sources contained various types of geospatial data, and data for the cartographic presentation were normalized for comparative purposes. Data were normalized in the range of 0 to 1 , relative to the highest value in the dataset. In addition, data from cartograms and thematic maps generated by the local authorities were normalized relative to the reference unit area. Various types of data were presented using GIS tools (ESRI 2021) to facilitate an assessment of Polish regions' potential for the development of outdoor and water tourism, including kayaking. 


\section{RESULTS AND DISCUSSION}

1. Polish outdoor tourism market - analyses of the Polish Tourism Organization (PTO)

Central-Eastern Europe is experiencing increased international tourist arrivals as an attractive destination for outdoor tourism activities. According to the PTO (2016), foreign tourists highly value Poland for its unspoiled nature and a wide variety of active recreation options. The most popular types of outdoor recreation are hiking, biking and kayaking.

The results of surveys involving foreign tourists indicate that Poland is regarded as a country with a diverse offer in the outdoor tourism category. Unlike the Czech Republic and Hungary, Poland boasts a wide variety of services in the segment of outdoor and adventure tourism. The results of a survey conducted among Belgian tourists confirm the above observation (Figure 3). A growing number of visitors from Western and Eastern Europe travel to Poland to participate in outdoor tourism activities in natural surroundings (PTO 2017, 2016). Other authors have previously made similar observations (Burneika and Kriaucinas, 2007; Brelik, 2009; Barkauskas, 2015). The PTO marketing strategy for 2012-2020 (PTO, 2011) emphasised kayaking. For kayaking in Polish regions, the availability of navigable waters was evaluated separately for domestic and foreign (German) tourists (Table 1). Table 1 data were visualized on maps in Figure 4. According to the PTO, marketing efforts targeting domestic tourists should focus on north-eastern Poland. In contrast, kayaking tours for German tourists should be promoted mainly in north-western and eastern Poland.

\section{Potential of Polish regions for the development of outdoor tourism, including water tourism - kayaking}

\section{a. Evaluation of geographic potential based on geospatial databases in the public domain}

Water tourism and kayaking tours require a well-developed hydrographic network. Therefore, geospatial databases in the public domain were analyzed to evaluate the potential of Polish regions to provide water tourism services and organize kayaking tours. In the first step of the analysis, bodies of standing water and rivers were identified in the Database of Geographic Objects on 1:250000 scale (BDOO_250). Their location was presented on vector maps (Figures 5a and 5b).
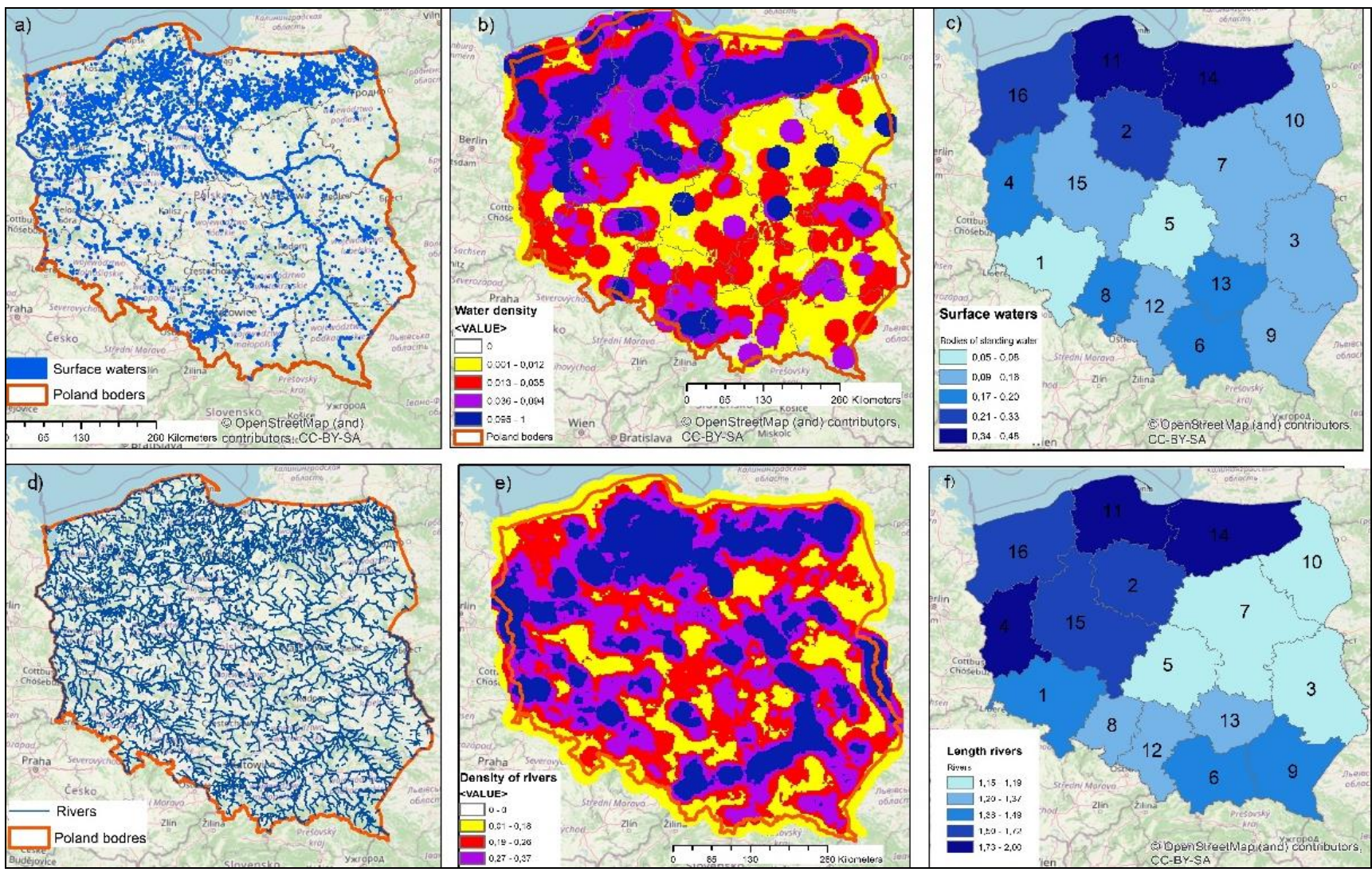

Figure 5. Bodies of standing water and rivers in Poland: a) bodies of standing water on a vector map;

b) bodies of standing water on a raster map; c) bodies of standing water in $\mathrm{km}^{2} /$ voivodeship area; d) rivers on a vector map; e) rivers on a raster map; f) rivers in km/voivodeship area (Source: own study on database BDOO_250 and used GIS tools)

Raster maps (Figure 5b and 5d) were generated in the Geographic Information System (GIS) - ArcGis (ESRI 2021) application and preseneed on base map from OpenStreetMap (OSM)platform ${ }^{1}$. Vector maps (Figures 5a and 5d) present bodies of standing water (3027) and rivers (1241) with registered geographic names. Rivers channels span a total length of $27,150 \mathrm{~km}$, and river segments intersecting bodies of standing water have a combined length of 19,701 km. Therefore, the total length of potential kayaking routes is $44,614 \mathrm{~km}$. Raster maps were generated by dividing datasets into subsets and calculating quantiles with five class breaks. The density of the visualized objects was normalized in the range of 0 to 1 . The area of the water bodies visualized in Figure 5 is presented in Table 2, separately for each Polish voivodeship. Table 2 data were expressed per unit area in each voivodeship, and the results are presented in cartograms in Figure 5c, f. 
Table 2. Potential for developing water tourism (kayaking) in Polish voivodeships (Source: own study on database BDOO_250)

\begin{tabular}{|c|l|c|c|c|c|c|}
\hline & Voivodeship & $\begin{array}{c}\text { Voivodeship } \\
\text { area }\left[\mathrm{km}^{2}\right]\end{array}$ & $\begin{array}{c}\text { Forest } \\
\text { area }\left[\mathrm{km}^{2}\right]\end{array}$ & $\begin{array}{c}\text { Area of standing } \\
\text { water bodies }\left[\mathrm{km}^{2}\right]\end{array}$ & $\begin{array}{c}\text { Length of } \\
\text { rivers }\left[\mathrm{km}^{2}\right]\end{array}$ & $\begin{array}{c}\text { Number } \\
\text { of rivers }\end{array}$ \\
\hline 1 & Lower Silesia & 19936 & 5549 & 156 & 2970 & 109 \\
\hline 2 & Kuyavia-Pomerania & 17948 & 4174 & 474 & 3084 & 85 \\
\hline 3 & Lublin & 25134 & 5634 & 362 & 2935 & 93 \\
\hline 4 & Lubusz & 13990 & 7029 & 252 & 2475 & 97 \\
\hline 5 & Lódź & 18194 & 3833 & 98 & 2168 & 66 \\
\hline 6 & Małopolska & 15166 & 4313 & 305 & 2216 & 85 \\
\hline 7 & Masovia & 35529 & 7903 & 401 & 4094 & 145 \\
\hline 8 & Opole & 9400 & 2496 & 182 & 1283 & 60 \\
\hline 9 & Podkarpacie & 17844 & 6642 & 280 & 2656 & 107 \\
\hline 10 & Podlasie & 20193 & 6040 & 244 & 2394 & 89 \\
\hline 11 & Pomerania & 18305 & 6645 & 872 & 3566 & 127 \\
\hline 12 & Silesia & 12317 & 4034 & 157 & 1684 & 59 \\
\hline 13 & Swiętokrzyskie & 11697 & 3224 & 235 & 1466 & 52 \\
\hline 14 & Warmia-Masuria & 24151 & 7251 & 1088 & 4831 & 140 \\
\hline 15 & Wielkopolska & 29797 & 7642 & 402 & 4858 & 143 \\
\hline 16 & West Pomerania & 22896 & 8217 & 751 & 3867 & 145 \\
\hline
\end{tabular}

\section{b. Institutions that organize and promote outdoor tourism (KRS, CEIDG)}

Poland's two business registers: the National Court Register (KRS) ${ }^{2}$ and the Central Register and Information on Economic Activity (CEIDG) ${ }^{3}$. Entrepreneurs who are not natural persons, i.e. associations, social and professional organizations, or foundations, are registered in KRS. In turn, natural persons conducting business activity (self-employed) are registered in CEIDG. The data obtained from these registers were analyzed to determine the number of businesses providing outdoor tourism and kayaking tourist services.

\section{Analysis of databases in the National Court Register (KRS)}

The databases of the National Court Register were searched based on registered company names. The following keywords were used: tourism, tourist, tour. The root word in the search was the tour? where the question mark denoted all possible characters. A total of 1814 records were identified, including 975 associations and 839 entrepreneurs. The search based on the keywords recreation and recreational (recreation?) produced 376 entries, including 230 associations and 146 entrepreneurs. In the group of 230 associations, 215 entities were affiliated with the Polish Tourist and Sightseeing Society (PTTK), and 69 entities were additionally identified when the acronym PTTK was used in the search (Table 3).

Table 3. Associations and companies registered in KRS whose business names contain the searched key words

(Source: own study on selected data from KRS)

\begin{tabular}{|c|c|c|c|c|c|}
\hline \multirow{2}{*}{$\begin{array}{c}\text { KRS } \\
\text { Number of } \\
\text { searches }\end{array}$} & tour? & recreation? & $\begin{array}{c}\text { Polish } \\
\text { Tourist and } \\
\text { Sightseein } \\
\text { g Society }\end{array}$ & PTTK & kayak? \\
\hline Total & 1814 & 376 & 285 & 69 & 63 \\
\hline Associations & 975 & 230 & 215 & 45 & 52 \\
\hline Entrepreneurs & 839 & 146 & 70 & 24 & 11 \\
\hline
\end{tabular}

The search was then narrowed down to kayaking tours, and the applied keywords were kayak/ kayaks/kayaking. A total of 63 records were found, including 11 companies and 52 associations. The geographic location of the identified entities is presented on a map in Figure 6. Most of these organizations are seated in south-western Poland. In addition, five kayaking associations are registered in the Polish capital of Warsaw, including the "Habazie" Academic Kayaking Club and "Kajakowa Dzieciom" Foundation for Education and Sports. It should be noted that the geographic location of kayaking tour organizers registered in KRS is not correlated with the location of water resources presented in Figure 5.

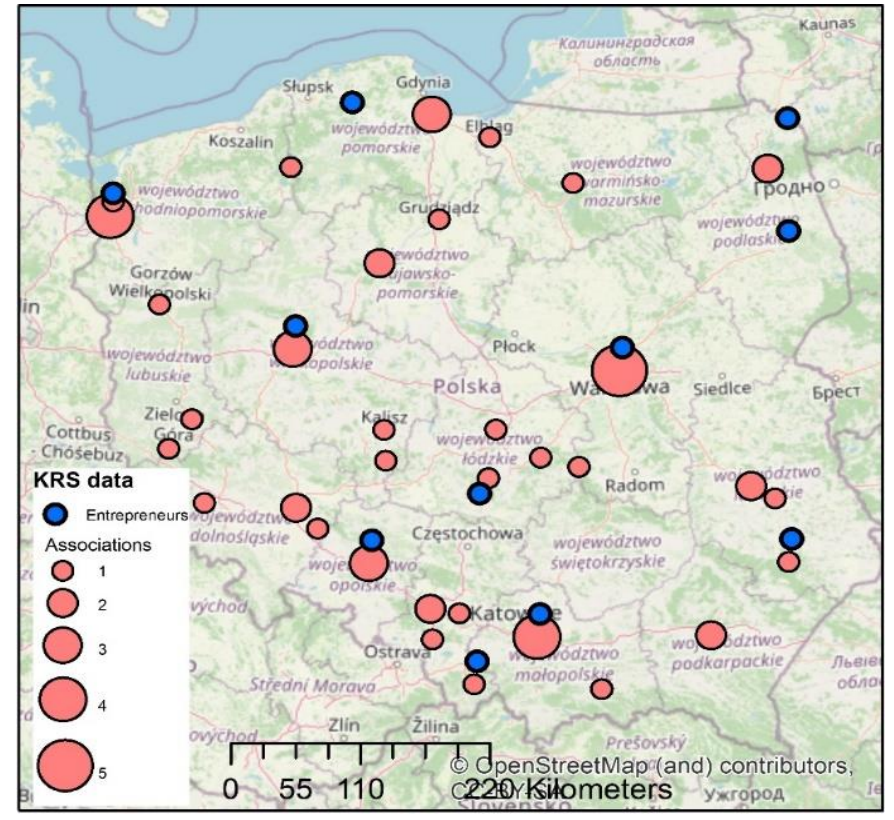
associations) registered in KRS whose business names contain the keyword kayak? (Source: own study on selected data from KRS, basemap of OSM and used GIS tools)
Figure 6. Location of tourism operators (entrepreneurs and

Analysis of databases in the Central Register and Information on Economic Activity (CEIDG)

It was assumed that most kayaking tour organizers and tourists use the rented equipment. Many Polish businesses rent

\footnotetext{
${ }^{2}$ https://ekrs.ms.gov.pl/web/wyszukiwarka-krs/strona-glowna/index.html

https://aplikacja.ceidg.gov.pl/CEIDG/CEIDG.Public.UI/Search.aspx\#
} 
kayaking equipment. These types of businesses were identified in CEIDG and localized in an attempt to determine the potential of kayaking-related tourism. Entrepreneurs who are natural persons (self-employed) are registered in CEIDG. They are assigned a Polish Classification of Activities (PKD) code that denotes the type of conducted business activity. For example, PKD code $7721 \mathrm{Z}$ denotes economic activities involving rental and charter of recreational and sports equipment:

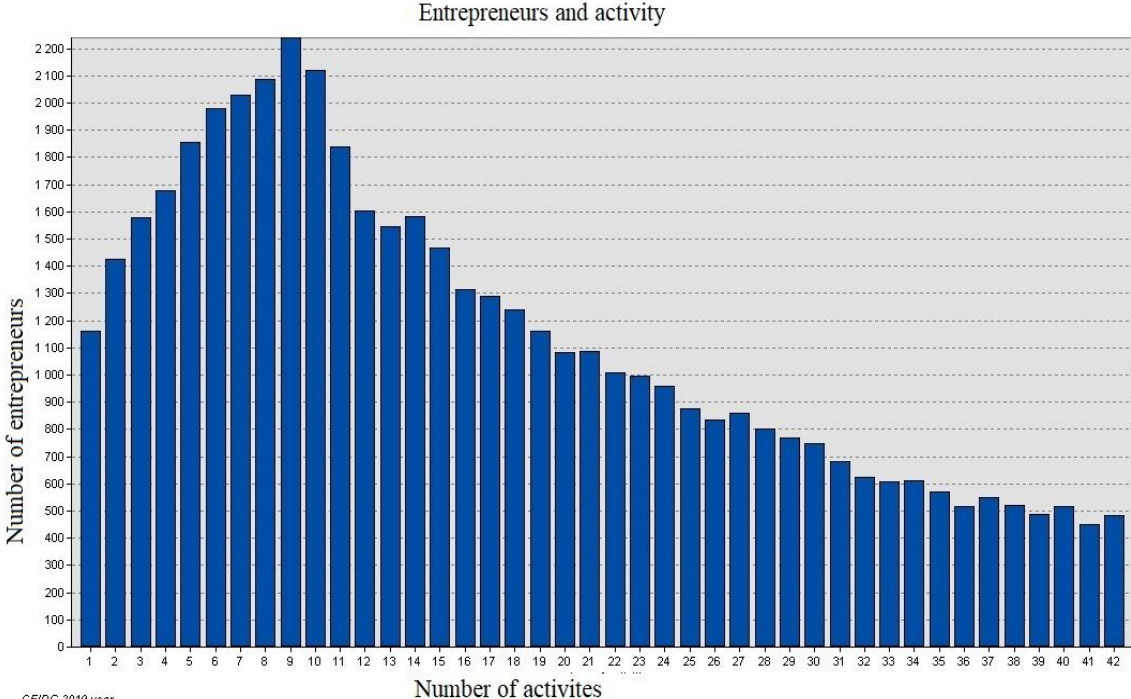

Figure 7. Number of entrepreneurs registered in CEIDG who declare various types of business activities, including the activity represented by PKD code $7721 \mathrm{Z}$ ? (Source: own study on selected data from database CEIDG)
- tour boats,

- kayaks,

- sailboats,

- bicycles,

- beach chairs and parasols,

- skis,

- other recreational and sports equipment.

It should be noted that this category of business activity does not include the rental of tour boats and yachts that are chartered with the crew or the rental of sports and recreational equipment that is owned by recreational centres. PKD code $7721 \mathrm{Z}$ represents businesses that provide tourist and recreational services and rent kayaks for kayaking tours. An analysis of the CEIDG database revealed that 53,380 Polish businesses operated under PKD code $7721 \mathrm{Z}$ in 2020 . The analyzed database

covered all CEIDG entries since 1970, including entries relating to businesses that had terminated or suspended their operations. However, businesses registered in CEIDG rarely declare only one type of business activity and, therefore, they are assigned more than one PKD code. In the total number of 53,380 identified businesses, only 1160 had operated solely under PKD code $7721 \mathrm{Z}$ (Figure 8). The remaining entrepreneurs were also engaged in other types of business activity, mostly those represented by the following PKD codes:

- 5520Z: short-term (daily or weekly) accommodation services - 280 businesses;

- 9329Z: entertainment and recreational services - 105 businesses;

- 8551Z: sports education, sports and recreational activities -70 businesses.

The distribution of CEIDG entries based on the number of declared business activities is presented in Figure 7. The largest group of entrepreneurs had declared 9 types of business activity. A high number of CEIDG entries and PKD codes, including 7721Z, indicates that many entrepreneurs combine various recreation, tourism and sports services in their business operations. To process the acquired data in the GIS environment, the businesses identified in CEIDG databases were geocoded based on their registered address (by plotting x/y coordinates). Geocoded data were presented graphically on vector and raster maps. The geographic location of each business is marked with a point on the map (Figure 9). Each of the generated maps presents the number of entrepreneurs that had declared a given number of business activities. Clear differences in the density of address points can be observed between maps. In Figures 8c to 8e, the density of address points was highest in large urban agglomerations. The number of businesses whose operations are linked with the tourist sector was highest in the voivodeships of Masovia, Silesia, Pomerania and Lower Silesia. The number of tourism enterprises registered in north-eastern Poland, i.e. in the voivodeships of Warmia-Masuria and Podlasie, was not high.

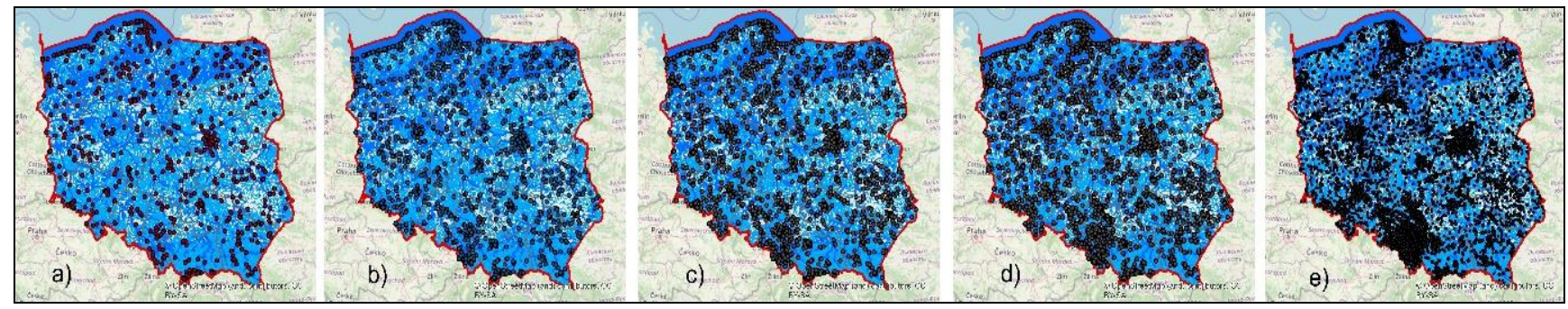

Figure 8. Location of businesses that rent and charter tourist equipment, including water sports equipment and kayaks: a) entrepreneurs operating under PKD code $7721 \mathrm{Z}$ only - 1160 entries; b) entrepreneurs declaring one and two types of business activity - 2585 entries; c) entrepreneurs declaring up to three types of business activity - 4163 entries; d) entrepreneurs declaring up to four types of business activity - 5842 entries; e) all entrepreneurs operating under PKD code 7721Z - 53,380 entries (Source: own study on selected data from data base CEIDG and used GIS tools)

The database acquired from CEIDG was modified for the purpose of detailed analysis. Entrepreneurs who had not terminated or suspended their business activity were selected, and entries with the same registered address were eliminated from the database (business activities conducted by family members were classified as a single enterprise). As a result, the 
analyzed database was reduced from 53,380 to 42,346 entries. The above difference represents the number of businesses that had been terminated or suspended in the last 46 years. The subset of 42,346 entries was subjected to further analysis.

The updated CEIDG data set was analyzed as time series data. The temporal distribution of CEIDG entries denoting businesses that were established in each year of the analyzed period (since 1976) and were active (as at 2020) is presented in Figure 9_1a. The number of businesses that were active in each year of the analyzed period is presented in Figure 9_1b. The analysis involved data for all of Poland (Figures 9a and 9b), and it was also performed separately for each Polish voivodeship (Figures 9_2-6a and 9_2-6b). The results of the analysis point to a gradual increase in the number of newly registered enterprises in the studied period. The greatest increase was observed between 2014 and 2018 . The number of active businesses remains high, but the number of newly established businesses has decreased in recent years. Data for selected Polish voivodeships are presented in Figures 9_2-6a. The temporal distribution of newly established businesses is similar in Masovia and Pomerania, where the number of newly registered businesses peaked in 2015 (Figures 10 2a, 2b, 3a, 3b). West Pomerania and Warmia-Masuria (rys 10_5a, 6a) have a much smaller number of businesses operating under PKD code 7721Z, but the number of enterprises in this category has been increasing steadily since 2007. These voivodeships are characterized by low levels of entrepreneurship despite considerable geographic potential for tourism development.

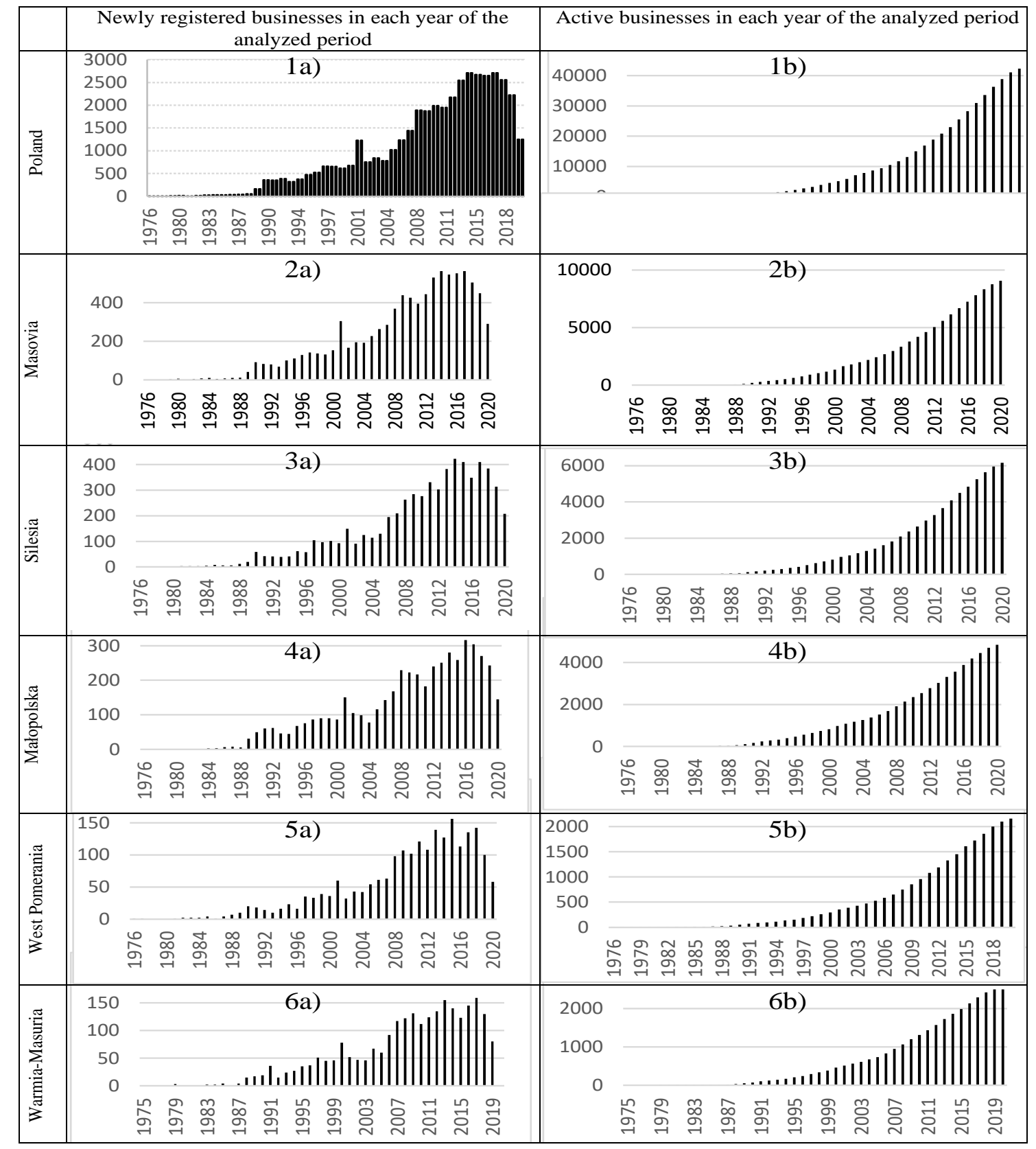

Figure 9. Selected data from the CEIDG database for all of Poland and selected voivodeships: Masovia, Silesia, Małopolska,

West Pomerania, and Warmia-Masuria; a) temporal distribution of newly registered businesses; $b$ ) number of active businesses in each year of the analyzed period. (Source: own study on selected data from data base CEIDG and used Excel tools)

As previously noted, the analysis involved only CEIDG entries relating to businesses operating under PKD code 7721Z. In the Polish climate, tourist and recreational equipment rentals generally operate on a seasonal basis, and 
entrepreneurs registered in CEIDG also conducted other business activities represented by different PKD codes. Enterprises operating solely under PKD code 7721Z (Figure $101 \mathrm{a}$ ) as well as businesses whose main economic activity was represented by PKD code 7721Z (Figure $101 \mathrm{~b}$ ) were selected from the CEIDG database for analysis. The resulting dataset of companies operating solely under PKD code $7721 \mathrm{Z}$ comprised 428 enterprises, and the dataset of companies whose main economic activity was represented by PKD code 7721Z comprised 1973 businesses (Figure 10 1a, 2a).

The analysis revealed that 1973 enterprises provided services mostly in the area of outdoor tourism. The distribution of these businesses across Polish voivodeships is presented in Table 4. The location of the above companies is presented on vector maps, raster maps and cartograms in Figures 10. The geographic location of the analyzed enterprises is presented on vector maps in Figure 10 1a, 1b. The density of the evaluated businesses across Polish voivodeships is presented on raster maps in Figure $102 \mathrm{a}, 2 \mathrm{~b}$. The density of the analyzed businesses in each Polish voivodeship, normalized relative to the reference unit area (per $100 \mathrm{~km}^{2}$ of voivodeship area) is presented in cartograms in Figure 10 3a, 3b. The largest clusters of companies operating under PKD code $7721 \mathrm{Z}$ were observed in northern, central-eastern and southern Poland. The lowest entrepreneurship levels were noted in central and central-eastern Poland.
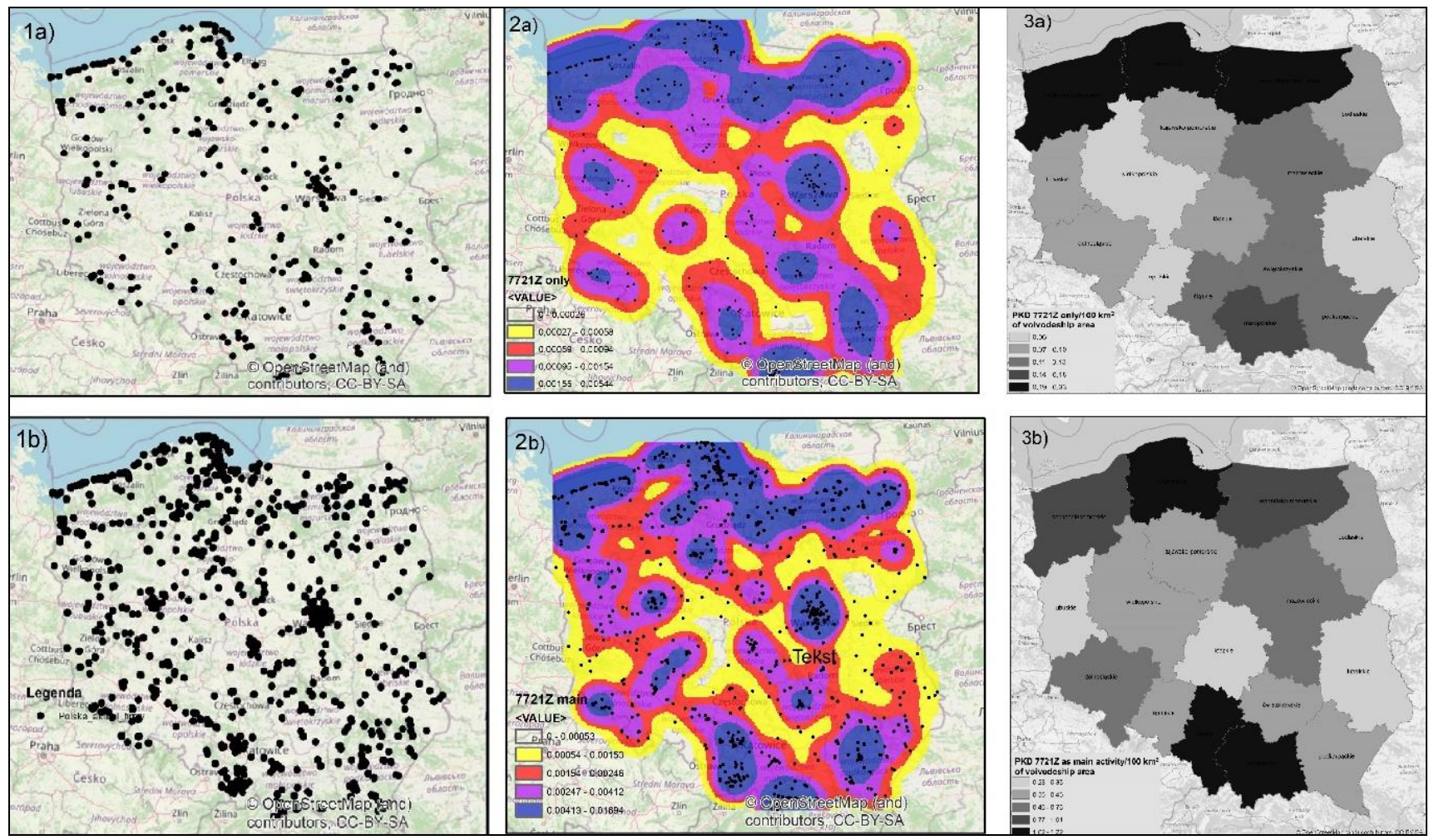

Figure 10. Location of active businesses after the modification of the dataset: 1a) businesses operating solely under PKD code 7721Z; 1 b) businesses whose main economic activity was represented by PKD code 7721Z. Raster map (cluster analysis) of the geographic location of active businesses (as at 2020): 2a) operating under PKD code 7721Z only; 2b) businesses whose main economic activity was represented by PKD code 7721Z. Location of active businesses (as at 2020) in Polish voivodeships:

3a) businesses operating under PKD code $7721 \mathrm{Z}$ only; 3b) businesses whose main economic activity was represented by PKD code $7721 Z$ (Source: own study on selected data from data base CEIDG and used GIS tools)

Voivodeships in northern Poland were characterized by a high number of companies operating in the area of outdoor tourism (Figures 12 and 13) as well as considerable natural resources for the development of outdoor tourism (Figures 6 and 13). Voivodeships in southern Poland ranked second in this respect (Figures 6, 7 and 13).

\section{Kayaking tour organizers registered in CEIDG}

In the following stage of the study, an attempt was made to identify kayaking tour organizers registered in CEIDG. It was assumed that the main type of business activity would be reflected in the company's name. The database was searched for businesses whose name contained the word kayak?, where the question mark denoted all possible characters (kayak/kayaks/kayaking). The database was searched on 26 May 2021 before the beginning of the tourist season when Covid-19 restrictions had been in place. A total of 242 companies whose names contained the word kayak? were identified (kayak-7, canoe -5). Other keywords relating to outdoor tourism were also used in the search (bicycle, skis). The word bicycle was identified in the name of 14 companies, the word skis - in 45 companies. The location of businesses whose registered name contained the word kayak is presented in absolute values (Figure 14a) and in values normalized relative to the reference unit area in each Polish voivodeship (Figure 14b). Masovia and Pomerania were characterized by the highest number of registered businesses that organize kayaking tours (Figure 14a). The number of kayaking tour operators relative to the reference unit area in each voivodeship was highest in Pomerania, Masovia, West Pomerania, and Lódź. Two of these voivodeships, Masovia and Łódź, are located in central Poland which is generally deficient in rivers and lakes. 
Table 4. Number of businesses operating in the area of outdoor tourism in Polish voivodeships (Source: own study on selected data from data base CEIDG)

\begin{tabular}{|c|l|c|c|}
\hline & Voivodeship & $\begin{array}{l}\text { Number of businesses } \\
\text { operating solely under } \\
\text { PKD code 7721Z }\end{array}$ & $\begin{array}{l}\text { Number of businesses whose } \\
\text { main economic activity was } \\
\text { represented by PKD code 7721Z }\end{array}$ \\
\hline 1 & Lower Silesia & 19 & 152 \\
\hline 2 & Kuyavia-Pomerania & 14 & 80 \\
\hline 3 & Lublin & 15 & 58 \\
\hline 4 & Lubusz & 12 & 49 \\
\hline 5 & Lódź & 16 & 59 \\
\hline 6 & Małopolska & 27 & 185 \\
\hline 7 & Masovia & 41 & 204 \\
\hline 8 & Opole & 6 & 40 \\
\hline 9 & Podkarpacie & 24 & 78 \\
\hline 10 & Podlasie & 15 & 87 \\
\hline 11 & Pomerania & 61 & 217 \\
\hline 12 & Silesia & 15 & 149 \\
\hline 13 & Swiętokrzyskie & 15 & 50 \\
\hline 14 & Warmia-Masuria & 63 & 243 \\
\hline 15 & Wielkopolska & 17 & 122 \\
\hline 16 & West Pomerania & 68 & 200 \\
\hline
\end{tabular}

Similar observations were made in the analysis of KRS data (Figure 7). These results indicate that the availability of outdoor tourism services/kayaking tours is affected not only by natural resources, but also by other factors. The results presented in Figure 11 are somewhat simplified because not all businesses that organize kayaking tours have the root word kayak in their registered name. Some kayaking rentals known to the authors are registered under completely different names (Pirat (Pirate), Szuwary (Reeds), Sptywy (Expeditions)). Despite the above, the results presented in Figure $11 \mathrm{~b}$ are quite surprising because the POT strategy for promoting kayaking tour organizers does not include the voivodeships of Masovia and Łódź. Further research is needed to explain these discrepancies.
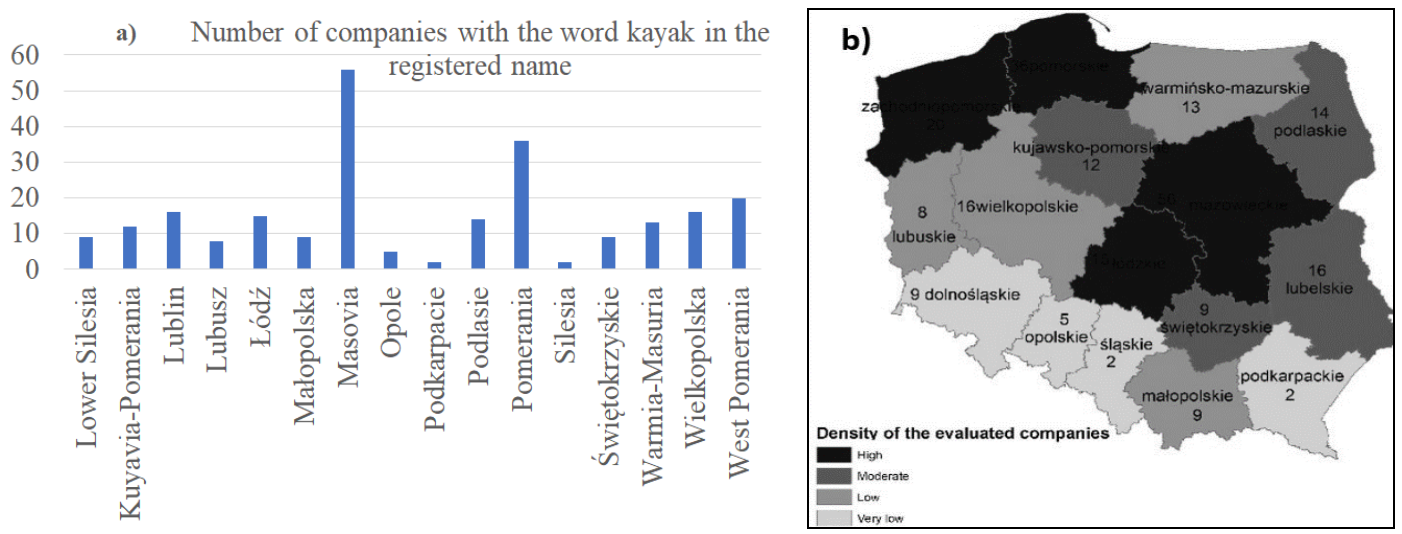

Figure 11. Number of companies whose registered name contains the word kayak: a) in absolute values; b) in values normalized relative to the reference unit area (cartogram) in each Polish voivodeship (Source: own study on selected data from data base CEIDG and used GIS tools)

\section{SUMMARY AND CONCLUSIONS}

An analysis of geospatial databases (Geoportal), business registers (KRS, CEIDG) and strategy documents developed by the PTO revealed that Polish voivodeships have considerable geographic potential for the development of outdoor tourism. The number of companies affiliated with the PTTK suggests that outdoor recreation is a highly popular form of active recreation in Poland. An analysis of business registers also demonstrated that outdoor tourism services, including kayaking tours, are offered by a large number of Polish companies and natural persons conducting business activity (self-employed). The results of this study point to high levels of local entrepreneurship associated with outdoor tourism. Sports equipment rentals are registered in all Polish voivodeships. These factors should drive the commercialization of the outdoor tourism sector, including kayaking tours. This segment of the tourist industry lacks comprehensive information, cohesive marketing and promotional strategies, and it requires further support.

The study also demonstrated that tourism development in Polish voivodeships is not proceeding in a sustainable manner. Regions with a high potential for tourism development are not promoted by the PTO. In this study, Masovia emerged as a hub of outdoor tourism activities (including kayaking), but its potential was disregarded in the PTO strategy. The PTO marketing strategy for Polish tourism for 2012-2020 listed regions that were most recommended for the promotion of outdoor tourism, including kayaking. However, tourists' preferences for participating in kayaking tours in different voivodeships do not match the recommendations of the PTO.

Further research is needed to identify other factors that contribute to the popularity of kayaking tours in Polish voivodeships, including logistic factors (accommodation, transport, local conditions) and the visitors' expectations. The popularity of outdoor tourism will continue to increase if the COVID-19 pandemic contributes to a further rise in nationalist and tightening borders. The growing demand for water sports equipment testifies to the above. Unlike in 2018 and 2019, water sports equipment had been reserved early in 2021, and it was in short supply during the tourist season.

\section{Acknowledgement}

The authors would like to thank public institutions (Main Office of Geodesy and Cartography, Ministry of Justice, Ministry of Development and Technology) for providing access to public databases. We thank also the Center for Scientific Geospatial Analyses and Satellite Computations (CENAGIS) for providing integrated geospatial database for the needs of this study.

\section{REFERENCES}

Balaguer, J., \& Cantavella-Jorda, M. (2002). Tourism as a long-run economic growth factor: the Spanish case. Applied Economics, 34(7), 877-884. https://doi.org/10.1080/00036840110058923

Barkauskas, V., Barkauskiene K., \& Jasinskas, E. (2015). Analysis of Macro Environmental Factors Influencing the Development of Rural Tourism: Lithuanian Case. Procedia - Social and Behavioral Sciences. 213, 167-172. https://doi.org/10.1016/j.sbspro.2015.11.421 
Brelik, A. (2009). Rural Touris M Development in Poland. Scientific Annals of the Association of Agricultural and Agribusiness Economists [Roczniki Naukowe Stowarzyszenia Ekonomistów Rolnictwa i Agrobiznesu], 11 (6) , 17-20. http:/agro.icm.edu.pl/agro/element/bwmeta1.element .agro-d68e41 c5-a6a6-4f37-a66b-dac9974372fd?q=bwmetal.element.agro-d210d0cd-0c6f-48e2-bf0b-9da2a97040dd;24\&qt=CHILDREN-STATELESS

Burneika, D., \& Kriaučiknas, E. (2007). Some premises for balanced development of ecotourism on the territory of Lithuania. Ekologija, 53, 10-15. https://www.researchgate.net/publication/266182549_Some_premises_for_balanced_development_of_ecotourism_on_the_territory_of_Lithuania

Butler, R., Hall, C.M., \& Jenkins, J. (1997). Tourism and recreation in rural areas. John Wiley and Sons Ltd. SBN: 978-0-471-97680-6. https://www.wiley.com/en-us/Tourism+and+Recreation+in+Rural+Areas-p-9780471976806

Copp, C.B., \& Ivy, R.L. (2001). Networking Trends of Small Tourism Businesses in Post-Socialist Slovakia. Journal of Small Business Managemen. 39, (4), 345-353. https://www.tandfonline.com/doi/abs/10.1111/0447-2778.00031 ?journalCode=ujbm20

Folgado-Fernández, J., Di-Clemente, E., Mogollón J., \& Campón-Cerro, A. (2018). Water Tourism: A New Strategy for the Sustainable Management of Water-Based Ecosystems and Landscapes in Extremadura (Spain), Land. 8. 2. https://doi.org/10.3390/land8010002

Fossgard, K., \& Fredman, P. (2019). Dimensions in the nature-based tourism experiencescape: An explorative analysis. Journal of Outdoor Recreation and Tourism, 28, 100219

Giddy, J.K., \& Webb, N.L. (2016). The influence of the environment on motivations to participate in adventu re tourism: The case of the Tsitsikamma. South African Geographical Journal. 98, 2, 351-366. https://doi.org/10.1080/03736245.2015.1028990

Godtman, K., Kling, Margaryan, L., \& Fuchs, M. (2018). (In) equality in the outdoors: gender perspective on recreation and tourism media in the Swedish mountains. Current Issues in Tourism. 23(2), 233-247. https://doi.org/10.1080/13683500.2018.1495698

Gössling, S., Hall, C.M., \& Skott, D. (2015). Tourism and Water. Book. Channel View Publications, Toronto. ISBN:9781845414993

Gössling, S., Peeters, P., Hall, C.M., Ceron, P.P., Dubois, G., Lehmann, L.V., \& Scott, D. (2012). Tourism and water use: Supply, demand, and security. An international review. Tourism Management. 33 (1), 1-15. https://doi.org/10.1016/j.tourman.2011.03.015

Gössling, S., Scott, D., \& Hall. C.M. (2021). Pandemics, tourism and global change: a rapid assessment of COVID-19. Journal of Sustainable Tourism. 29 (1), 1-20. https://doi.org/10.1080/09669582.2020.1758708

Grzelak, M.M., \& Roszko-Wójtowicz, E. (2020). Tourist attractiveness of voivodeships in Poland in the light of selected indicators: a dynamic approach. Economic Annals-XXI. 183 (7/8), 161-177. https://www.ceeol.com/search/article-detail?id=931503

Hall, D. (2020). Sustainable tourism development and transformation in Central and Eastern Europe. Journal of Sustainable Tourism. Taylor \& Francis, 8(6), 441-457. https://doi.org/10.1080/09669580008667379

Hegarty, C., \& Przezborska, L. (2005). Rural and agri-tourism as a tool for reorganising rural areas in old and new member states-a comparison study of Ireland and Poland. International Journal of Tourism Research. 7(2), 63-77. https://doi.org/10.1002/jtr.513

Hughes, H.L., \& Allen, D. (2009). Central and Eastern Europe and EU accession 2004: Views of the impact on tourism. Tourism and Hospitality Research, 9(3), 185-198. http://dx.doi.org/10.1057/thr.2009.9

Ivy, R., \& Copp, C. (1999). Tourism patterns and problems in East Central Europe. Tourism Geographies. 1(4), $425-442$. https://doi.org/10.1080/14616689908721335

Klitsounova, V. (2020). Networking, Clustering, and Creativity as a Tool for Tourism Development in Rural Areas of Belarus. In: Slocum, S.L., \& Klitsounova, V. (eds) Tourism Development in Post-Soviet Nations, Palgrave Macmillan, Cham. 155-173. https://link.springer.com/book/10.1007\%2F978-3-030-30715-8

Korzeniewski, J., \& Kozłowski, M., (2020). Development of tourism in Polish poviats in the years 2010-2017. Quality \& Quantity. 54, 1591-1612. https://doi.org/10.1007/s11135-019-00923-4

Lewandowicz, E. (2018). Spatial conflicts in areas particularly attractive to tourists. 18th International Multidisciplinary Scientific GeoConferences SGEM 2018. Conference proceedings, 18, Informatics, Geoinformatics and Remote Sensing Iss. 2.3: Photogrammetry and Remonte Sensing, Cartography and GIS, STEF92 Technology Ltd, 2018, 575-582. https://doi.org/ 10.5593/sgem2018/2.3/S11.073. https://www.sgem.org/index.php/jresearch-article?citekey=Lewandowicz201811575582

Niewiadomski, P. (2018). Geography, tourism studies and post-communist transformations in Central and Eastern Europe. Tourism Geographies, 20 (1) 182-184. https://doi.org/10.1080/14616688.2017.1399443

Marciszewska, B. (2006). Tourism in Poland: Changes in Policy, Management and Education, in: Hall, D., Smith, M. and Marciszewska, B. (eds.) Tourism in the New Europe. Wallingford: CABI, 127-36. https://doi.org/10.1080/14616680802236410

Mazurski, K.R. (2000). Geographical perspectives on Polish tourism. Geojournal, 50 (2/3), 173-179.

Paesler, R. (2007). Der Wandel des Tourismus in den Transformationsländern Ostmittel- und Osteuropas durch die politische Wende [The change of tourism in the transition countries of Central and Eastern Europe through the political turn], in: Becker, C., Hopfinger, H. and Steinecke, A. (eds) Geographie der Freizeit und des Tourismus - Bilanz und Ausblick [Geography of recreation and tourism - Conclusion and prospects]. München: Oldenbourg, 555-567. https://doi.org/10.1524/9783486700015.555

Saarinen, J. (2017). Tourism and geopolitics: issues and concepts from central and Eastern Europe, edited by Derek Hall , Journal of Sustainable Tourism, ISBN: 9781780647616. https://doi.org/10.1080/09669582.2017.1400786

Szromek, A. (2013). Pomiar funkcji turystycznej obszarów za pomoca wskaźników funkcji turystycznej na przykładzie obszarów państw europejskich, (The Measurement of Tourism Function of Areas Using Indicators of the Tourism Function on the Example of Areas of European Countries). Studia Ekonomiczne / Uniwersytet Ekonomiczny w Katowicach, (Economic Studies /University of Economics in Katowice). 132, 91-103. http://bazekon.icm.edu.pl/bazekon/element/bwmeta1.element.ekon-element-000171251507

Szromek, A. (2012). Wskaźniki funkcji turystycznej. Koncepcja wskaźnika funkcji turystycznej i uzdrowiskowej. (Tourism Function Indicators. The Concept of Tourism and Health Resort Function). Publishing House of the Silesian University of Technology) (in Polish), Book, 1- 293, ISBN: 978-83-7335-916-1.

*** PTO (2011). Marketingowa strategia polski w sektorze turystyki na lata 2012-2020 (Marketing strategy of Poland in the tourism sector for 2012-2020, accessed on 12 November 2021. https://www.pot.gov.pl/pl/o-pot/plany-i-sprawozdania-pot/marketingowastrategia-polski-w-sektorze-turystyki-na-lata-2012-2020-2

*** PTO (2016). Obcokrajowcy o Polsce (Foreigners about Poland). accessed on 12 November 2021. https://www.pot.gov.pl/pl/dane-iwiedza/dane-i-wiedza/badania-i-analizy

*** PTO (2017). Analiza rynków za rok 2016 objętych działaniami Zagranicznych Ośrodków Polskiej Organizacji Turystycznej (Analysis of the markets for 2016 covered by the activities of Foreign Centers of the Polish Tourist Organization). accessed on 12 November 2021. https://www.pot.gov.pl/pl/dane-i-wiedza/dane-i-wiedza/badania-i-analizy

*** PTO (2019). Zagraniczny ośrodek polskiej organizacji turystycznej w Brukseli sprawozdanie, rok 2019. ZOPOT Belgia [Foreign center of the polish tourist organization in Brussels report 2019. Zopot Belgium]. (accessed on 12 November 2021). https://www.pot.gov.pl/pl/dane-i-wiedza/dane-i-wiedza/badania-i-analizy 